\title{
CHARACTERIZATION IN BENAVENTE AND LORCA
}

Laurentino Suárez

The dramatists, Jacinto Benavente and Federico García Lorca, created in their plays some of the most electrifying and representative female characters of the modern Spanish scene. It is already well known that Lorca's women supply the main interest of his dramas and are symbolic of his deepest meanings. Woman for Lorca represents the true combination of physical and spiritual forces found in society. He tries constantly to reach the essence of humanity, and, to this end, female characters are his most important vehicles. Woman is the essence par excellence, whose influence illuminates the dramatic elements, thus providing a basis for a truly poetic play. Human, feminine, profound, universal, she is the heroine whose personality permeates the entire work.

Prior to Lorca, Jacinto Benavente was also fascinated by woman and the multiple effects that she generated within society.

Even though the plays of these two masters are very different not only in concept but also in technique and in the use of characters as artistic elements within the play itself, both dramatists showed many similarities in their interpretation of the role of woman. Problems arise when a comparison is made between both writers. This article will attempt to investigate the female characters from the point of view of their artistic function within the play.

At the very beginning the variety of Benavente's characters is an obstacle to any comparison with Lorca's characters. It would be almost an impossible task to reduce Benavente's themes and characters to a pattern, but his style is fairly constant.

There is a great difference between Raimunda (La Malquerida) and Silvia (Los Intereses Creados). The latter is a character without real impact; she has an important role but it is not fully developed. As a result she gives a rather weak impression. On the other hand, Raimunda and even Acacia in the first play are the central strength of the play, not only as elements in the plot and action but also as representative women of society. In this rural tragedy Benavente used an introspective technique in sketching the two women, their expressions, their strong passions and sentiments as well as their mutual frustrations. $\mathrm{He}$ even deals with their repressed subconscious desires. The play is characterized by strong dramatic tension and play of character, a technique that Gonzalo Torrente Ballester has called "escamoteo," "la sustitución sistemática de la acción por la narración 0 por la alusión, en el escamoteo de los momentos dramáticos." 1 
In Señora Ama, Dominica represents another feminine type. The symbolism of the title suggests that she is "masterful," "just," "domineering." She is a heroic figure who controls not only the action of the play but also most of the other female characters. She is close to the definition of a "complete woman," thus illustrating the hidden significance of her name, Ama. This is another tragedy rooted deep in humanity - the frustration of a woman incapable of fultilling her greatest desire, mother-hood.

On the other hand, in Los Inereses Creados, Sirean, Colombina, and Silvia, even though they are important characters, are only superficially treated.

Benavente enjoys playing with his public. He leads them to believe something, gives them impressions of the characters - impressions which he diliberately destroys later on. A good example is found in Señora Ama (II, 9) ${ }^{2}$ when Maria Juana turns out to be very different from the character she was first thought to represent. Benavente purposely misguides his audience by letting them see Maria Juana through Dominica's eyes. Another example of the same technique occurs in La Malquerida when the audience is convinced of Esteban's wickedness by Raimunda: she dominates the stage, and what she feels and believes automatically influences those who watch her. It is not until Acacia takes over that another perspective is opened, thus throwing a new light on the action. The audience learns of other factors that motivate Esteban and Acacia (III, 4, 7). ${ }^{3}$

In Lorca's plays, the theme, tone, and characters change little during the action, and his female characters are like variations on one and the same theme - the theme of heredity and sexual frustration. This theme appears in Benavente but not with the consistency found in Lorca's poetical dramas. A character like Benavente's Dominica dominates and changes the other characters and even influences the audience, but the play ends on a positive and optimistic note. In Yerma, Doña Rosita la Soltera, La casa de Bernarda Alba, and Bodas de Sangre, however, Lorca plunges his audience into a sea of passion and frustration which intensely involves the spectator.

The role of the woman in Benavente's theater is versatile, and in certain plays, like Señora Ama and La Malquerida, his feminine characters are very similar to Lorca's. They can be analyzed from two related points of view: first, they express a different system from those of Lorca, and second, when the characters have similar values, they appear in totally different contexts. For example, Raimunca and Acacia in La Malquerida and Dominica in Señora Ama are comparable to a certain extent with Lorca's Yerma of Yerma, the mother in Bodas de Sangre, and Bernarda in La casa de Bernarda Alba. Immediately the audience notices in the life of these women the mysterious forces of blood relationship - la fuerza de la sangre.

Raimunda's second marriage (with Esteban) has remained sterile, just like Yerma's and she suffers from the uncontrollable obsession which distinguished the mother in Bodas de Sangre and Bernarda in La casa de Bernarda Alba. This obsession produces the catastrophe when it imposes, or attempts, to impose: social law (matrimony) on wild emotion. From the beginning Acacia (La Malquerida) hints strongly about her sentiments for Esteban and shows clearly a lack of enthusiasm for Faustino: 
Later on, the death of Faustino proves that passion cannot be tamed by convention. Since she was from the begining the obstacle to fulfillment and therefore the cause of the tragic tension, by murdering Raimunda Esteban relieves his thwarted passion.

Although in many ways a realist, Benavente, by the use of tragic irony, introduces a strong poetic element into his plays. La Malquerida, for example, begins with a gay scene at a party, progresses steadily through the development of complicated problems, and ends in tragedy. As Raimunda herself says:

Nunca va y vienê, de ande quiers que sea, que no se acuerde de traerle also... No se acuerds tanto de mí, y nunca me he sentido por eso; que al fin es mi hija, y el que la quiera de ese modo me ha hecho quererle más. ${ }^{5}$

Symbolism is abundant throughout La Malquerida; Isabel remembers Faustino because she once saw him knocked down by a bull; when Acacia is burning the last letter of Norberto, she hears the shot that kills Faustino, and so forth.

The restaints imposed by religion are much weaker in Lorca than in Benavente: "Lleva tú el rosario," says Raimunda when she hears of Faustino's assassination, "yo no puedo ni rezar," "esa madre, esa madre." The impression is that some emotions are deeper than those imposed by religion.

Although often set against a different scale of values, sexual frustration also appears in both. Dominca resembles Yerma; her reaction toward children she sees is the same that Yerma feels toward Marís's child. Both women suffer from their sterility. Señora Ama might be classified as a comedy since it has a positive ending. The frustration disappears when Dominica is found to be pregnant, even though Benavente maintains the suspense of her supposed sterility unitl the last moment. The play contains no foreboding elements, and the spectator may therefore hope for a happy ending.

Dominica is a complete woman; she has the same feelings as Yerma and doña Rosita and is also a central character. But she turns into a positive figure: thus she gives the play an almost optimistic tone, while in Lorca's tragedies the audience never escaped from the fatalities of passion.

La Malquerida Lies somewhere between these extremes. Whereas it ends in inevitable tragedy when Esteban murders Raimunda, it implies that Acacia and Esteban will enjoy a moment of happiness, even though a brief one. Benavente is trying to satisfy his public by winding up the plot: he leaves his public no loose ends and provides a solution to the play, just as he did in Señora Ama. Lorca in his poetical intensity leaves his audience unsatisfied: after the curtain has fallen they torment themselves for days trying to penetrate the world of passion, a world alien to most men who will never be able to fully understand it. In Bodas de Sangre, this poetical intensity is an increasing progression that finally explodes at the end. When "la Novia" escapes with Leonardo, the mother condemns her son in order to purgue the honor of the family and satisfy the ereditary hate. From this moment on (Act III), the play's symbolism becomes more ntense. The figures of the moon, the wood choppers, the beggar, the young girl are petical devices that suggest death. In this play as well as in Señora Ama there is a kind of peasement, since the mother does not want to revenge herself on the Novia. Instead of 
accentuating the dramatic tension of the play, the author evokes a realm of passion which must forever remain enigmatic. The drama ends with an elegy to the essence of the play itself: the knives, symbol of creation and destruction.

The feminine figures in Lorca's Bodas de Sangre, Doña Rosita la Soltera, Yerma, and La casa de Bernarde Alba are of great poetical intensity. They exist in a real world, but not so real and appealing to the human senses, or rather to the exterior, as are Benavente's. Lorca's figures are directed more to the interior world which is created by the poetical language used by the artist. Thus the established rhythm by a given character as the dialogues of two of them is very appropriate to that mysterious vitality that emanates from within. Lorca creates a new world, a world of imagination and intemporality. He was the Salvador Dalí of scenography.

On the other hand, in Benavente's language it is noticeable that his characters have a particular accent or some noticeable characteristic that identifies them. They exist in the temporal world; they represent real people that already have an established existence and are identifiable because of common peculiarities. That is why, in spite of the evident depth of Raimunda, the audience never completely understands her nature. She hinders this by using a facade. That poetic world of Lorca, that world which is impossible to define and enclose in conventional barriers, is not sensed in Benavente. The emotions of Lorca are so abundant that the audience is engulfed in a sea of extreme sentiments that are of such an impact that they became involved in a series of emotions that are identifiable by both sexes. By creating a type of heterosexuality in his artistic approach, Lorca is able to create emotions felt by both men and women, thus creating in theory, al least, this duality as far as the audience response goes, and making possible this paradoxical blend of sexes at the emotional and poetical levels.

The feminine character represented by both dramatists gives them the opportunity of representing on the stage the vital force that conducts our daily actions and reactions, that mysterious elan that has always puzzled mankind and will continue to do so for centuries to come. These characters are well-defined figures as far as representing the weaker sex, but the approach and vision of the characters are not the same. Despite the fact that they might be sympathetic with that world, neither Benavente nor his public existed in a truly dramatic world. His characters are self-images representing the idea of mirror-image; they are the audience identifying themselves and others with the stage characters. Lorca's characters, as well as his public, are plunged into the mirror and go beyond the realm of imagination to find themselves in an incomprehensible world of depth and mystery, a world that has never been unveiled to them before by any other Spanish dramatist, a world of essence, of symbols, and of agonizing desperation. Despite the fact that Lorca tried to obtain his plays from real occurrences and portray them as truly photographical documents he seems to have forgotten his primary. He creates a race of brave and unconquerable women who are to a certain extent real people. His creative imagination mixes colors and folklore to produce a world of lorquianismos. 


\section{NOTES}

${ }^{1}$ Torrente Ballester, Gonzalo. Teatro Español Contemporáneo. Madrid, 1957. pp.41-42.

${ }^{2}$ (II, 9) María Juana - ¡P Porque no ha llegado una que ha sabío quitártelo!

Dominica $-{ }_{i}$ Quién iba a ser ésa?

María Juana - Yo lo hubiera sió, pa que lo sepas, pa que no lo agradezcas ahora...

Dominica $\quad-{ }_{\mathrm{i}}$ Falta que él hubiera querió!

María Juana - ¡El bien querría, como quiere a toas! Y voy a decirte más... Yo le quería también, como no he querío a ninguno...

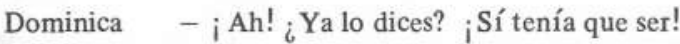

${ }^{3}$ (III, 4) Acacia - No, no la quiero como tenía que haberla querido si ese hombre no hubiera entrao nunca en esta casa. Si me acuerdo de una vez, era muy chica y no he podido olvidarlo, que toa una noche tuve un cuchillo guardao ebajo la almohada, y toa la noche me estuve sin dormir, pensado na mas que en ir a clavárselo.

${ }^{4}$ (II, 7) Esteban - Eso me digo yo ahora. ${ }_{i}$ Por qué ha muerto

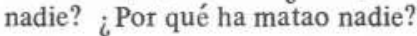

Rubio - Eso, usted lo sabrá. Pero cuando se confiaba usted de mí, cuando me decía usted un día y otro: "Si esta mujer es pa otro hombre no miraré naa." Y cuando me decía usted: "Va a casarse, y esta vez no pueo espantar al

que se la lleva, se casa, se la llevan de aquí, y ca vez que lo pienso..."

${ }^{5}$ Benavente, Jacinto. La Malquerida. Colección Austral No. 84. Madrid, 1964. pp.21. Idem. p.13. 